\title{
UNCERTAINTIES OF TRANSNATIONAL BELONGING: HOMELAND NATIONALISM AND CULTURAL CITIZENSHIP OF LITHUANIAN IMMIGRANTS IN THE USA
}

\author{
Vytis Čiubrinskas \\ Professor of Social Anthropology \\ Head of the Center of Social Anthropology \\ Vytautas Magnus University, Lithuania \\ Email:vciubrin@siu.edu
}

\begin{abstract}
The processes of trasnationalism, especially large-scale migration from Eastern Europe (e.g. Poland, the Baltics, and the Balkans) are visible in the creation of new realities through the representation of cultural differences and distinctive social experiences enacted in diasporas. The aim of this article is to show how social ties and resources are used by migrants to cope with challenges of transnational belonging from grass-roots level understanding of the complexities of intra- and inter-ethnic relations enacted by the last two waves of the Lithuanian immigration in the USA, based on the fieldwork conducted in Chicago in 2002-2003, 2007, and 2013. Social belonging of the forced (end of WWII refugees) wave of migration was challenged by the political subjectivity applied to any immigrant group, including exiles from communism, resisting the assimilation into the melting pot politics dominant in America. The economic wave of post-socialist immigrants of the 1990s was challenged by the uncertainty and precarity of their lives and jobs, especially in terms of their legal status, command of the official language, and professional skills. Homeland nationalism and cultural citizenship are addressed in this article as strategies of coping with the aforementioned uncertainties. Homeland nationalism of the forced migration wave along with the practices of ethnification was marked by the moral imperative of 'to cherish the home country' and helped to withstand the 'melting pot' America. Cultural citizenship of the labor migrants appears as moral economy brought from the homeland and used for inter-ethnic networking of immigrants from the Eastern European region as compartmentalized lifestyle to cope with marginalization, especially of those without papers.
\end{abstract}

Keywords: cultural citizenship, diaspora, homeland nationalism, identity, transnationalism 
Upon the collapse of colonial and communist regimes, social uncertainty, distrust of collective formations and social institutions continue to characterize postcolonial and postsocialist societies. This becomes evident with heightened mobility and a rise in migration. New and mobile livelihoods are forged in which mobility does not necessarily mean deterritorialization, but rather a multiple in-placement making, and according to Karen Fog Olwig and Ninna Nyberg Sorensen, an expansion of space through personal as well as family livelihood practices that occur in two or more places (Olwig \& Sorensen 2002). This raises the question of how the migrants themselves decide on new forms of bonding and loyalty to the places and the states.

The best examples of this are strategies and practices of transnational immigrants, because by participating in transnational networks, becoming part of a mobile livelihood (ibid.), and forging transnational loyalties (Vertovec 2009) they are contextualized in new local contexts (country of immigration) and newly formed ways of life within the diasporas and beyond their borders.

The transnational condition of migrants is also related to the effects of power leverage, especially when national states in late modernity tend to categorize immigrants as culturally radically different because they are understood, first and foremost, as being from another country, and therefore seen as culturally radically different from locals (Olwig 2003: 66). In their own turn immigrants take up countervailing strategies to cope with this and other uncertainties, among which the most common is ethnification. The question of descent, understood as originally belonging to a trans-local place, and homeland-related narratives become important for them, and this is why they essentialize their own histories, cultures, and identities in order to give importance to concepts like 'kinship' or 'native land' (Krohn-Hansen 2003: 86). Immigrants who arrive in a new country usually appear in the position of an ethnic minority, which brings about a shift in their identity as well as the construction of a new loyalty to the host country and a reaffirming of loyalty to one's country of origin. Hence, the dimension of transnationalism becomes especially important for revealing not only how diasporic bonds based on ethnic organizations are constructed, but also how sociocultural ties, which overstep the bounds of one country, are constructed, and new loyalties to the state(s) appear.

To understand migrants' sociocultural ties from an anthropological perspective, it is important to consider migrant experiences and knowledge of cultural behavior that were brought over from the country of origin as cultural capital. It is precisely through these cultural ties and cultural heritage that we can see the intersection of diasporas and homelands. Louise Ryan and others, who have researched the Polish immigration in London, use the theoretical framing of social capital to draw attention to the fact that the diversity of social networks 
of immigrants strongly depends on cultural capital, especially when forging connections across networks with those beyond the boundaries of the ethnic community (Ryan et al. 2008: 676; Parutis 2014: 39).

In this sense Christian Giordano's ethnographic research on the Chinese in Malaysia $(2003,2011)$ is remarkable. For instance, when addressing the question of determining bonding among people affected by transnational migration, he demonstrates the importance not only of the bonds that form among immigrants in the host country, but also their foundation that stems from the country of origin (Giordano 2013: 199). He thus determines that the deep axis of bonding among the Malaysian Chinese is around clan relations (ibid.: 217).

This article focuses on the socio-cultural ties and resources used by migrants and their descendants for their strategies and practices of belonging in the case of Lithuanian immigrants in the United States, particularly in Chicago, which since the turn of the twentieth century has been the home to the largest number of Lithuanians residing outside of Lithuania. Overall, more than 100,000 Lithuanians or Lithuanian-background Americans lived in the larger Chicago at the end of the twentieth century (Kuzmickaitè 2003: 76). The Lithuanian emigration to the United States has been continuous for at least a century and a half. We can speak of three waves of migration and at least five generations of Lithuanian-background population in the United States and, according to the US Census of 2010, their number is estimated to be 654,000 (Cidzikaite 2013).

I will concentrate on the two last waves of migration: the forced migration of refugees fleeing from the communist regimes in postwar Eastern Europe in the late 1940s, and the labor migration of the late 1980s and early 1990s, after the end of the Cold War.

The first, political wave of the Lithuanian immigrants carried the refugees of World War II and immediately after, who were fleeing the communist regime in Eastern Europe, to the displaced persons (DP) camps in the liberated Nazi Germany, and later to the United States and other Western countries. Of the about 70,000 Lithuanians who passed through these camps, at least 30,000 settled in the United States, primarily in the cities of the East and Midwest, and 12,000-15,000 in Chicago, as a result of the US Displaced Persons Act of 1948 (Kučas 1975: 287, 297-298). As the ties with the country of asylum grew stronger with each new generation, these displaced persons, so-called DPs, started to feel that America was their second homeland. However, their nationality was a fixed, pre-given, and invariable category to which they stayed faithful. Their experiences in the DP camps in Western Germany became a source of social memory for later generations and an example of a countervailing strategy for how to live in a country (e.g., the United States), without really becoming a part of it. Their experiences in the exile camps in Germany taught them how to 
live in a society to which they did not really belong, and actually this wave of Lithuanian immigrants can be addressed as diaspora in the classic sense of the term (cf. Cohen 1997). These exiles identified with Lithuania as their homeland and even more so - as the nation-state to which they were loyal and to which they belonged as nationals, although it did not exist anymore on the world map as it was occupied by the Soviets. So, by becoming political immigrants in the United States, they applied precisely this strategy, which developed into diasporic nationalism. Eventually, the DPs, especially the second and third American-born generations, created a dual Lithuanian-American identity, and their diasporic identity became characterized by dual loyalty to both Lithuania and the United States.

In earlier established definitions of diasporic identity, the term 'diaspora', usually involving forced migration and traumatic experiences of expulsion, and Jewish and Armenian displacement, has often served as a model (Safran 1991, 2004). It is still used to describe the transnational ties of migrants who have endured expulsion or involuntary exile to their remembered or imagined homelands (Cohen 1996; Levitt 1998: 928). Such symbolic ties to the homeland are usually shared in the host countries among the forced migrants and their descendants as a symbolic source of resistance to assimilation into the host society, and are often forged into diasporic nationalism, extensively described by social anthropologist Nina Glick Schiller as 'homeland nationalism' and 'long distance nationalism' (Glick Schiller \& Fouron 2001). All the three (diasporic, homeland, and long distance nationalism) could be understood as synonyms, so I would prefer to use homeland nationalism which is a conspicuous example of migrant identity empowerment and, according to Steven Vertovec, could be understood as 'politics of homeland' and 'politics of nostalgia' (Vertovec \& Cohen 1999).

The second, post-Cold War economic wave of migrants started to arrive in the United States after the fall of the Berlin Wall and noticeably accelerated after Lithuania regained its independence in 1990. Between 1988 and 2000, there were about 20,000 'new Lithuanians' in Chicago alone (Kuzmickaitè 2003: 76). These labor immigrants of relatively low socio-economic status had to compete with other immigrants (mostly from Central and Eastern Europe) in the labor market. Due to this competition the 'new Lithuanians' used to rely on maintaining old and establishing new social networks based on kinship, neighborhood, or friend relationships as countervailing practices to survive. These social networks often intersected ethnic boundaries by becoming trans-ethnic networks which included immigrants from different post-socialist countries Poles, Ukrainians, Russians, etc. - who shared the same Eastern European socialist past, common social and economic experiences, and remembered the 
poignant narratives as well as facilitated mixed marriages and festive culture (Čiubrinskas 2018).

As it is widely proven, international labor migrants and refugees usually care for their cultural distinctiveness to be recognized and valorized, and easily become motivated to claim ownership of their cultural heritage practices and identity by constructing histories about their roots and by shaping their public and political practices of homeland (Malkki 1992). Thus immigrant ethnification becomes one of the countervailing strategies against uncertainty and challenges of migrant livelihoods as well as their lifestyles often categorized as 'strange cultures'. The response to that is often essentialist, pointing to the exclusiveness of cultural resources and cultural embeddedness of immigrants. Such cultural embeddedness could be seen as a model of cultural citizenship, which also includes social experiences, values, norms, and rules of conduct transmitted from the homeland. In this case, the approach to citizenship as a prime expression of loyalty is altered by the concern with the moral and performative dimensions of membership beyond the domain of legal rights (cf. Glick Schiller \& Caglar 2008: 207). In this case cultural citizenship that refers to the "right to be different" (Rosaldo \& Flores 1997; Brettell 2008 [2003]) in terms of ethnicity, native language, religion, and other resources (cf. Nick Craith 2004) can be altered by the 'social culture' of the shared moral economy as social remittances brought from the homeland.

Both waves of Lithuanian immigrants, the political and the economic one, have been influenced by enculturation at home, i.e., models of knowledge and behavior rooted in their homeland(s) (in the same country but under very different regimes) and this process could be interleaved by features of the livelihoods and lifestyles of the host country and the locality of their residence (in this case Chicago). Such a cultural identity 'transplanted' or transmitted from abroad could reflect the limited integration, even enclave the type of life of immigrants who uphold cultural models created elsewhere (in our case, in the pre-Soviet Lithuanian nation state or in the country occupied by the Soviets). So here come questions: What are commitments to the country of origin and the country of residence? How do the local and trans-local socioeconomic contexts help to form and change relationships of these Chicago immigrants and how do they express their belonging, loyalties, and dependencies?

In order to have a closer look at these and similar issues, I examined the trajectories of Lithuanian immigrants' ties and strategies of their belonging shaped as homeland nationalism and cultural citizenship. The socio-cultural belonging of transnational migrants is almost never certain and stable and is often challenged by the receiving state's institutions and dominant discourses, as it was the case with the 'melting pot' politics used in the United States until 
the 1960s-70s. At the time, it was some sort of political subjectivity applied to any immigrant group including exiles from Eastern Europe, who resisted any assimilation and were keen to build an alternative to 'Sovietized Lithuania' by creating homeland nationalism-focused ethnic communities. Much later, in the early 1990 s, the post-socialist labor immigrants had to challenge the questioning of their legal status. Many of these 'new migrants' have transgressed the regulations of the previously existing visa regime and even up to now continue to live in the United States without papers. According to Kripienè's study of Lithuanian immigration in New York, based on an analysis of the US Yearbook of Immigration Statistics, around 25,000 Lithuanians who had the status of illegal migrants, became legal in 2001-2010, while around 1,300 were deported or returned (Kripienè 2012: 26). These immigrants also faced considerable uncertainty by mingling in precarious jobs, having a limited command of the state language, professional skills, etc. One of the ways they coped with that was by applying personalized networks of acquaintances and a moral economy of exchange of favors (cf. Ledeneva 2018), which they had acquired in communist Europe as a culture of 'spinning' - the extensive use of social networks of friends of friends and co-workers (Lankauskas 2014: 53).

So my aim in this paper is to address homeland nationalism and cultural citizenship as strategies for coping with uncertainties of the transnational positioning of migrants along with their countervailing practices of ethnification and inter-ethnic networking within in-groups. Hence, the dimension of transnational belonging becomes especially important for revealing not only how diasporic bonds work as ethnic networks, but also how social habits that overstep the bounds of one country are constructed.

To provide answers to these questions I used, among other sources, some historical researches published on Lithuanian migration to the United States (Kučas 1975; Budreckis 1982; Senn 2005), and anthropological fieldwork-based studies: Liucija Baškauskas' research done in Los Angeles in the late 1960s (cf. Baškauskas 1981, 1985 [1971]) and Daiva Kuzmickaitè's more recent research in Chicago, in which attention has been drawn to migrants' practices. Kuzmickaite claims she was among the first to understand "what it means to be a new Lithuanian immigrant in Chicago" (2003: 13). These were followed by Ieva Kripiene's research on post-socialist immigrants in New York (Kripienè 2012), which demonstrated how the issues of ethnicity, identity, and practices of tight networking bonded the immigrants.

My own ethnographic materials were obtained in the course of fieldwork (participant observations in situ along with in-depth interviews, focus-group interviews and life histories) conducted among immigrants from Lithuania and Lithuanian Americans in Chicago in 2002-2003 (seven months) and in 2007, 
as well as two-month fieldwork in 2013. Even though before undertaking field research I expected that these immigrants lead a closed life in the local Chicago ethnic communities or, perhaps the opposite, are freely surfing the waters of the multicultural megalopolis or even completely disappear in the melting pot of the larger American society, my research revealed a different reality. It appeared that immigrants create and recreate relations among co-ethnics in in-groups but also cross ethnic boundaries (post-socialist immigrants in particular) by establishing trans-ethnic sociocultural ties as well as by joining the local and trans-Atlantic social networks. In addition to (participant) observations, indepth interviews were also conducted with 30 individuals in various areas of Chicago, the majority of whom resided in Gage Park in the inner city, as well as in Chicago's suburbs, primarily Darien and Lemont. The research encompassed a total of 14 sites: two Lithuanian Saturday schools, a business club, two Lithuanian community centers, three companies founded by Lithuanian immigrants (transportation and delivery services), and five restaurants (two of which specialized in Lithuanian food). Participant observation involved taking part in and observing events - including their preparation, intermissions, and aftermaths - such as concerts, basketball tournaments, business club meetings, celebration of Lithuanian national holidays, Lithuanian restaurants and groceries as well as daily routines at transportation companies, the Lithuanian community centers and Saturday schools. Numerous informal conversations helped to identify the most popular narratives and discourses. Two focus group studies were conducted - with workers and with students.

\section{EXILES’ AMBITION OF HOMELAND NATIONALISM}

Robin Cohen insists on understanding diaspora through cultural traits and collective representations inherent to diasporic phenomena (Cohen 1997: 26). According to Christian Giordano, diasporas are often understood as just "shared culture", but it is more precise to approach these as "a culture-based corporate group that often takes on actual institutional forms in the shape of associations, brotherhoods, clubs, committees, etc." (Giordano 2011: 66). Thus diasporas as cultural units share (at least to a degree) common sets of cultural knowledge, including interpretations of history, concepts of identity, value systems, and moral imperatives. So, diasporas could be addressed as ethnic communities and social networks based on trust, codes of moral duty, and engaged in homeland nationalisms (Benovska-Sabkova 2013; Čiubrinskas 2013).

There are clear historical reasons for homeland nationalism to be traced in the Lithuanian diaspora in the United States. During the period from the 1940s, 
when Lithuanian independence was lost due to the Soviet occupation, until the reestablishment of the Republic of Lithuania in 1990, the trope of 'retaining the Lithuanian nation', which became stateless for fifty years, was crucial for most of the Lithuanian Americans as descendants of political emigration of the late 1940s. This trope urged the return and rebuilding of homeland, and became enacted just before, during, and especially after the reestablishment of the independent Lithuanian republic, in the late 1980s and early 1990s.

The DP wave of political immigrants included many middle-class professionals who founded the Lithuanian-American Community (LAC) in 1951 as a branch of the World Lithuanian Community (WLC) established by the Supreme Committee for the Liberation of Lithuania in Hanau, Germany, in 1949 (Kučas 1975). The WLC became an umbrella organization for diasporic Lithuanians. The fact that the United States never recognized the Soviet occupation of the Baltic States was at the core of the nationalist imperative "to stay Lithuanian everywhere and forever", enforced as a "moral duty" for those who "were lucky in a situation where others were not" (Budreckis 1982: 198), as most of these Lithuanian immigrants had lost relatives and friends in the Soviet deportations to Siberia of the 1940s and early 1950s.

The LAC and related organizations vigorously opposed the communist rule in their homeland and demanded that émigrés avoid Soviet institutions; "relations with Lithuania should be limited to private contacts because contacts with officials of the Lithuanian Soviet Socialist Republic might compromise the U.S. government's policy of non-recognition of Lithuanian incorporation into the USSR" (Senn 2005). The DPs' image of the home country and its people was pervaded by nation-state nationalism, from which springs a stereotype of Lithuanianness as an inborn and inscribed phenomenon. Their image of the home country was constructed from the typical political refugee experience. The occupied and suffering country, left behind at the end of World War II, encouraged them to take on a mission of regaining the nation and retaining its culture. The image of the 'homeland under siege' altered victimization (Kelly 2000) and brought together many Lithuanian Americans for political campaigns of emancipation, irredentism and liberation of the home country.

Localization of migrants in Chicago, i.e., a city which is historically known for its unique ethnic diversity, has developed by coping with marginalization and discrimination based on race or ethnicity even when they were not a visual minority as in the case of Lithuanians in Chicago. Therefore, the sociocultural ties of immigrants can be created as strategic ties which are directed against marginalization and even against integration, and may well become anti-integrational as it was the case with the DPs. In this sense diasporas can be understood not as closed (cultural) groups (communities), but as formations 
rising from specific strategic networks. In our case, the global umbrella organization - the WLC - serves as an eloquent example of such a strategic network that strengthens ethnic identity and cohesion while, simultaneously, creating various new models of social interaction and differentiation.

\section{THE LITHUANIAN CHARTER AS A MORAL CONSTITUTION OF THE HOMELAND}

The Lithuanian Charter was adopted in 1949 by the Lithuanian refugees in DP camps in Germany for maintaining and retaining their loyalty to Lithuania. In this document, the nation was described as a "natural community of individuals ... [where] a Lithuanian remains a Lithuanian everywhere and always" (LAC 2018). Here the nation was reified and its people (nationals) and culture (national) were treated in rather ethnic terms. Thus the mobilization of the nation became crucial for diasporic activities and could not be separated from retaining it in terms of culture, language, traditions, and heritage. Along with this, such tropes as 'Lithuanian family', 'Lithuanian homeland', and 'Lithuanian heritage' became emphasized in particular. So the Lithuanian Charter served as moral encouragement for taking a mission for those in exile (Čiubrinskas 2006), urging every Lithuanian to preserve the existence of the Lithuanian nation and to promulgate its cultural heritage, language, and traditions for future generations (LAC 2018).

In Jonathan Friedman's terms such a 'constitution' could serve as 'generic' identity (Friedman 1994: 72-73) based on and fueled by transmittable living heritage - language and traditions - and where each person becomes included as a 'link in the chain' in which culture must be learned, retained, and transmitted to the next generation, as one interlocutor stated:

I am a conduit of culture. I am a link in the chain. It was important for me to explain Lithuanian myths to my daughter, ... but not to teach American democracy. (Regina, personal communication, 2013)

With emphasis on intangible/living heritage, homeland nationalism is relatively free from territorial and legal boundedness (Levitt \& Glick Schiller 2004: 1021), and diasporas may employ ideas about heritages for the essentialization of homeland being categorized as culture-as-nation. Such a category applies mainly to political migrants/refugees, in this case the DPs, for whom homeland becomes elevated as an idealized place and a resource for nostalgic feelings. Thus a sense of belonging to the culture, associated with the homeland, has been constructed and has become an important resource for essentialist and reified culture to be retained. 


\section{RETAINING OF THE CULTURE-AS-NATION}

The moral imperative implied by the Lithuanian Charter developed into a strong sense of duty and mission, both moral and civic, to do what is possible to 'retain the Lithuanianness' assumed as culture-as-nation:

We were escaping from the [Soviet] occupation and it was such a sacred thing to retain the Lithuanianness (lietuvybe). Strictly speaking, only Lithuanian in families, and avoid integration ... it was like a protest against occupation. (Lithuanian-American woman, 75, personal communication, 2007)

Our parents ... were nurtured in the interwar spirit. It helped to keep Lithuanian culture; nurture the young generation, which could more or less speak Lithuanian. That nationalism helped to keep the Lithuanian spirit. (Lithuanian-American man, 55, personal communication, 2007)

It was an obvious task for diasporic people to take responsibility for instructing the younger generation and to reproduce the culture in ethnic schools, cultural organizations, and churches. The model of enculturation, used at home, in the DPs' families, implied, if not imposed, Lithuanianness for the second and even third generation of Americans born as Lithuanian Americans:

In my family parents didn't allow us to watch TV. While at home, we had to speak Lithuanian only. Each word pronounced in English was fined with a ten-cents fine. There were always some talks about Lithuania, as it needs to be helped to be liberated and that we will obviously return to it right after it is free. (American-born man, 51, personal communication, 2007)

The Lithuanian diasporic intelligentsia faced a problem of recreation, recodification, and new standardization of culture - of putting a displaced Lithuanian culture into a fixed framework. It was their ambition to create an alternative to Soviet Lithuanian culture by imposing a ready-made essentialist codification of the Lithuanian culture by, for example, producing textbooks for diasporic children to be used in ethnic classes with ethnic programs and literature.

However, most of the moral economy of second-generation American Lithuanians follows along the lines of helping the homeland as part of their 'learned' identity. This comes along with socialization into the American middle-class lifestyle with its norm of giving back to others when you are (more) successful. This was mentioned by some of my informants, including Arunas:

If you're successful in your career and have graduated from Harvard, as I have, you have an obligation to give back, to help, to support others... It is popular in America... alumni give a lot to their universities; for example, 
Harvard, my university, is a good example of this... State officials, even Obama, used to work in the public kitchen during Thanksgiving Day. (personal communication, 2013)

So the 'learned' identity of diaspora nationalism, sustained through the decades by politics of heritage, language, culture identity, and by narratives of the traumatic history of the nation that had suffered Soviet occupation, was ready to give back to the homeland. Idealism and a mission to help the country that had gotten rid of the Soviet rule in the early 1990s encouraged diasporic people to return and bring in their expertise - mainly, though not necessarily, in terms of professional specialization, and to provide professional, social, and material support.

Beginning in the late 1980s, the need for 'retained' and 'learned' identity obtained a new function. This time it was used to make a difference by gatekeeping to confront a massive influx of the new post-Soviet immigrants - fellow citizens, but with very different experiences and marked by the communist regime. The principal imperatives of the Lithuanian Charter started to be applied again, this time at the end of the twentieth century, to meet labor immigrants newly arriving in the United States from former communist countries.

\section{DE-CULTURED NEW LITHUANIANS IN CHICAGO}

From the very beginning of the post-Soviet Lithuanian immigration to Chicago, in the late $1980 \mathrm{~s}$, its impact on the Lithuanian diaspora life in the city was quite visible. In addition to the existent ethnic institutions established earlier, they formed a new Saturday school in Naperville, western Chicago, founded a newspaper Čikagos Aidas (Echo of Chicago), established a prestigious business club - the Chicagoland Lithuanian Rotary Club - and created the Chicago Lithuanian Basketball League which in 2013 had 15 teams. Also some companies managed by Lithuanians were founded, the most wellknown of which is the overseas packaging and shipping company Atlantic Express Corp.

However, all those initiatives and organizations did not fit well with the expectations of diaspora Lithuanian Americans expecting newcomers to join diasporic organizations with predominantly ethnic activities. New immigrant ties with the wider Lithuanian immigrant community and activities were frequent, very superficial, and full of uncertainty and disappointment. They often felt not acknowledged and supported by the former DPs, Lithuanian Americans, controlling most of the ethnic organizations (cf. Kuzmickaite 2003). As earlier research on recent Lithuanian immigrants in the United Kingdom has shown, 
their identity could be situational (Kuznecovienè 2009), which interferes with their ambition to retain Lithuanian culture and heritage and leads them to undertaking strategies that help manage the risk of marginalization, 'undocumented' status (Liubiniene 2009: 19), suspicion that they are to evade taxes (Kripienè 2012), and labeling as 'de-cultured'.

The conservative wing of Lithuanian Americans with the DP background invented a label for the recent immigrants, categorizing them as 'Little Soviets', marked by a lack of Lithuanian culture, having been 'contaminated' through exposure to communist culture, being de-cultured and de-nationalized by the Soviet regime. In this way diasporic Lithuanians (or at least part of them) pretended to the role of 'culture experts', providing guidance on approaching American society generally as well as on getting into the ethnic community (Čiubrinskas 2018).

Field research in the United States revealed that contemporary Lithuanian immigrants are unified through specific experiences and social interactions brought over from post-socialist Lithuania, and/or experiences of the post-Soviet past that are passed down through the older generation, which play an important role in distancing them from the remaining Lithuanian diaspora. These social networks of in-groups are especially used by undocumented immigrants (those who overstayed their tourist visas, before the visa requirement was abolished in 2009) as well as those who feel rejected because of their low job qualification and poor English skills. Instead of participating in ethnic communities or ethnic networks which bring old and new immigrants together, they tend to create in-groups or circles of their own people, which are very often inter-ethnic and transnational, acting across the state borders and transferring old models of Soviet moral economy to new places of migration as social remittances.

Such circles of one's own people and networks could be understood, using Alena Ledeneva's conceptualization of the moral economy of the Soviet era, which she defines as the economy of favors - maintaining of trust and mutual exchange of services and favors (Ledeneva 1998). It is one of the strongest links that connects the circles of 'one's own' people. Such a human relationship system based on the exchange of services and favors can also be seen as a form of social capital. In both cases it is simply a social resource which can be transferred as social remittances in the case of migration to another environment (Levitt 1998; Levitt \& Lamba-Nieves 2011). At the same time, it is a transnationalism-based phenomenon because it enables a social networking model which is international as it cuts across the state boundaries. Moreover, it is also inter-ethnic. 


\section{ETHNIC AND INTER-ETHNIC TIES, AND ONE'S OWN PEOPLE'S CIRCLES AS COMFORT ZONES}

One of the most popular forms of establishing and keeping up ethnic ties among the recent immigrants is through kids. Children actively attend ethnic (Saturday) schools, ethnic leisure clubs, and other similar activities. Many adults associate their free time with attending ethnic clubs and concerts that take place in schools, church halls, cultural centers or in Lithuanian restaurants where artists from the homeland perform. When informants were asked what bound them to other Lithuanians in Chicago, they usually mentioned four things: school, because they meet each other through their kids; the community center (socalled cultural house) (in Gage Park neighborhood once inhabited by the former waves of Lithuanian immigrants); basketball tournaments, and also private parties. Such ethnic institutions as Saturday schools or community centers function as umbrella organizations that provide a foundation for networking, which expands into the work sphere within Lithuanian companies (for example, Atlantic Express Corp., Unlimited Carriers, and others) and thus play a role in the way ethnicity is used as one of the primary means for sociocultural ties.

Nevertheless, as it was mentioned, the participation of post-socialist immigrants in 'Lithuanian activities' is full of uncertainty and oftentimes also disappointment. Even if they participate in the activities of Lithuanian institutions by attending Lithuanian Mass in Catholic Church, take their children to Saturday school (in some cases this involves a commute of several hours to Chicago from neighboring states such as Indiana), or partake in cultural events, they have a hard time receiving recognition and support from co-ethnics of the DP generations (Kuzmickaitè 2003).

So, they give priority to social strategies that help to develop social networks within their own circles instead. These in-groups of one's own are based on the common experience and the socioeconomic status acquired in the country of departure even before emigration, and maintained through the ties kept up with friends and former co-workers in the home country. Such one's own people's circles are very popular in Chicago among post-socialist immigrants from the whole Central and Eastern European region and can be assumed as an alternative not only to the dominant public organizations but also to the long-established ethnic institutions that had been founded by the earlier waves of immigrants. If ethnic institutions are led by a common goal to maintain diasporic identity and ethnification, one's own people's circles are created more transnationally by maintaining kinship-neighborhood-friendship ties across the Atlantic. Also individual ties are constructed through a personal invitation by an acquaintance to join some club or fellowship relationship which, 
in turn, makes one committed and creates social pressure to become one of one's own people with all the obligations of the reciprocity of favors.

So it is clear that the bonding of new immigrants is not sufficient to be understood within the framework of ethnic (Lithuanian) activities or those of relatives and families; it transcends national borders and ethnic lines and appears in a way as a construction of cultural citizenship done by those from the Eastern European region in the shape of a comfort zone. New Lithuanian Chicagoans do transcend ethnic boundaries and easily enter social networks with immigrants from other post-socialist Eastern European countries, especially Poles, Ukrainians, and Russians. They do this by entering the same one's own people's circles, using a mixture of Russian, English, and Polish as a lingua franca, sharing workplaces and neighborhoods in the southeastern part of the city.

So, they share social spaces and a certain common culture, leisure time activities (e.g. sharing Russian movies on rent in most Lithuanian shops), patterns of consumption (shopping in the same Polish and Lithuanian or Russian shops), festive cultures, and even a sense of humor. They are also accustomed to advertisements, other information and discourses from the local Eastern European-centered media (newspapers, radio channels) in all the three languages, namely Lithuanian, Polish, and Russian.

These mutual social spaces and activities could be defined as comfort zones; for example, workplaces, especially those where many or most employees are of immigrant Eastern-European background, become important arenas for the creation of a new social space. These social spaces are fueled by the experience and knowledge of practices of informal economy and bonds of trust transplanted from homelands. The fieldwork carried out in Chicago proves that such 'bonds of trust' appear to be enacted in the form of social remittances from overseas. This enacts friendships and acquaintances among post-socialist immigrants in order to achieve the public good by prioritizing and privileging one's own people, i.e., relatives, neighbors, co-workers, friends, etc. Thus, it is not so much a matter of economic need but of socially important cultural habits (Kopnina 2005: 138). Here bonds of trust and reciprocity of favors serve as a model of Eastern-European friendship and loyalty, which becomes a communalizing force for immigrants in the region. 


\section{LIFESTYLE IDENTITY AND CONSTRUCTION OF HOME AS A COMFORT ZONE}

As it was discussed above, immigrant ethnification could be seen as one of the countervailing strategies to cope with uncertainties and marginalization of immigrant life, which usually leads to essentialism and exclusiveness of cultural resources, and eventually to ethno-cultural embeddedness of immigrants. Such cultural embeddedness could work as a model of cultural citizenship, but in our case the culture of the recent Lithuanian immigrants in Chicago cannot be explained merely as ethnic or ethnically embedded, but it is rather shaped as a lifestyle. This was highlighted also by one of the interlocutors who said that "learning to live" is what ties them to America:

Learning to live in a material well-being perhaps ... it keeps us all here. If somebody told us that everything would turn upside down in Lithuania and you would be able to make the same money as here, that you could live the same life, I think, no one would ever have left [the country]. (Daiva, 26, personal communication, 2013)

In the articulation of loyalties to the home and host countries, the category of citizenship is neither an a priori indicator of loyalty nor an important part of belonging to a particular place. Cultural citizenship is used instead, and the connotation of a home as a place where a person belongs is a good example of how transnational loyalty and lifestyle are created. In their studies of the issue of belonging among the post-socialist Lithuanian immigrants in the United Kingdom, Neringa Liubinienè (2009) and Violetta Parutis $(2006,2013)$ note that when constructing home, immigrants presuppose their spectrum of obligation regarding both their country of origin and the country of residence. Migration (whether forced or voluntary) implies a diasporic or dual loyalty to both the origin and host countries.

In the case of Lithuanian diaspora formed by the refugees, the idealism related to the idea of home was created as an alternative and compensatory mechanism to the socially imparted trauma that the native home was destroyed by the communist regime. They give significance to Lithuania, their country of origin, not only as a state, but also as a birthplace or homeland, and relations of faithfulness, obligations, and loyalty secured through the networks of family and friends. Therefore, the real homes of the Lithuanian diaspora in Chicago (e.g. in the suburbs of Cicero and Lemont) were built as cultural collections (Clifford 1988) or as museums (Kockel 2002). Such 'homes' became an alternative to the true homes that were left overseas. It was like a museum for the inherited family relics as well as the newly created and collected national objects as the symbols of homeland. 
The construction of home among post-socialist Central and Eastern European labor migrants is directed to the recreation of home, which is based on social memory as well as on personal experiences of everyday life at home -in the country of origin. It is the construction of home as one's own space (Liubinienè 2009) that is based on tight relations with one's own people. Such a space is supported by intimate ties among one's own people, and is transferred to the diaspora and created in situ as a familiar space that acquires the meaning of the culturally produced 'home', i.e., home as a network composed of family, relatives, and friends. In other words, home becomes synonymous with a familiar space of one's own, and this also incorporates the in-group circle.

Such a production of home provides culturally anchored constructions of one's own space or one's own circle, or one's network of family, relatives, and friends (Liubinienè 2009). It is important to highlight the moments that help create ties with the country of residence as being the most important: a conspiracy of one's own group, aspiration for material well-being and "learning how to make a living" (ibid.). In these ties, there are no ethnic, national, or state identities present but just a livelihood and lifestyle.

In this way the understanding of cultural citizenship implies the understanding of not only cultural embeddedness but also rules of conduct transferred from overseas, and the challenging of dominant social rules of conduct and thus definitely enacting the Eastern European immigrants' right to be different. Also such cultural habits of one's own circles of in-group networking create own spaces as comfort zones with particular lifestyles that serve against categorization and marginalization, and also as some sort of substitute for the homeland.

\section{CONCLUSIONS}

The main pattern of the Lithuanian diasporic life in the United States from the late 1940s to the early 1990s is revealed in the Lithuanian Americans' commitment to retaining the homeland's culture and nationness through their standardization in textbooks for ethnic schools, models of enculturation in the families, and individuals acting as homeland culture experts or culture-asnation gatekeepers, especially for the newly arriving immigrant wave marked by the communist regime. Governed by a formula of 'how to be a Lithuanian in the free world', inscribed in the Lithuanian Charter of 1949, as well as being enculturated into the explicit ethnification and homeland nationalism of the diasporic life, descendants of the forced emigration wave were charged with the moral imperative to cherish the home country. It worked as firm countervailing strategy against the assimilationist melting-pot America, and was also used to 
guide post-Soviet immigrants to cope with the uncertainties of their belonging to post-melting-pot American multiculturalism.

Another pattern of the transnationally lived immigrant world, which applies to the contemporary wave of Lithuanians in Chicago, is marked by a continuous quest for the recognition of a particular distinctiveness and difference of collectivity, which is usually met by the normative legal institutionalization required to obtain citizenship status. Cultural citizenship appears here as a form of transnational belonging without formal citizenship agendas and also, as this paper shows, without culture in the sense of heritage or ethnic culture. It consists rather of social habits, rules of conduct, moral norms and loyalties, as well as social capital and social remittances brought from the homeland.

Post-socialist Eastern European labor migrants' ways of constructing their togetherness by creating social spaces is a good example of transnational belonging where new immigrants used to create compartmentalized lifestyle arenas that differed from ethnic enclaves and diasporas created by the former immigration waves, and were open to inter-ethnic networking with other immigrants from the Eastern European region. They used to create social spaces by sharing workplaces, being involved in inter-ethnic networking and making their own spaces as homes, as comfort zones of security to cope with uncertainty and precarity of lives and jobs, and especially of the legal status of those who are still 'without papers'.

\section{SOURCES}

Materials of interviews from 2002-2013 in possession of the author.

\section{REFERENCES}

Baškauskas, Liucija 1981. The Lithuanian Refugee Experience and Grief. International Migration Review, Vol. 15, No. 1/2, pp. 276-291. http://dx.doi.org/10.2307/2545343.

Baskauskas, Liucija 1985 [1971]. An Urban Enclave: Lithuanian Refugees in Los Angeles. New York: AMS Press.

Benovska-Sabkova, Milena 2013. Social Relations and Identity: The Russian Diaspora in Sophia. In: W. Kokot \& C. Giordano \& M. Gandelsman-Trier (eds.) Diaspora as a Resource: Comparative Studies in Strategies, Networks and Urban Space. Münster: LIT, pp. 89-103.

Brettell, Caroline 2008 [2003]. Anthropology of Migration: Essays on Transnationalism, Ethnicity, and Identity. Walnut Creek \& Lanham \& New York \& Oxford: Altamira Press.

Budreckis, Algirdas 1982. Reluctant Immigrants: The Lithuanian Displaced Persons. In: D. Cuddy (ed.) Contemporary American Immigration: Interpretive Essays. Woodbridge, CT: Twayne Publishers, pp. 173-205. 
Cidzikaitè, Dalia 2013. Kas yra Amerika ir kas Amerikoje gyvenantys lietuviai. [What Is America and Who Are Lithuanians Living in America.] Slaptai.lt, 12 August. Available at https://slaptai.lt/?s=Kas+yra+Amerika+ir+kas+Amerikoje+gyvena ntys+lietuviai, last accessed on 17 February 2020.

Čiubrinskas, Vytis 2006. "To Be of Use to Your Own Country": The Missionary Identity of Lithuanian Transmigrants. Socialiniai mokslai / Social Sciences, Vol. 3, No. 53, pp. 25-32.

Čiubrinskas, Vytis 2013. Diaspora as a Resource of Homeland Nationalism Forged Overseas and Contested Back Home: The Case of Lithuanian-Americans. In: W. Kokot \& C. Giordano \& M. Gandelsman-Trier (eds.) Diaspora as a Resource: Comparative Studies in Strategies, Networks and Urban Space. Münster: LIT, pp. 89-103.

Čiubrinskas, Vytis 2018. Transnational Chicago: The Local and Translocal Networks and Loyalties of Post-Socialist Lithuanian Immigrants. Diogenes, Vol. 22, pp. 1-11. https://doi.org/10.1177\%2F0392192117740040.

Clifford, James 1988. The Predicament of Culture: Twentieth-Century Ethnography, Literature, and Art. Cambridge, MA: Harvard University Press.

Cohen, Robin 1996. Diasporas and the Nation-State: From Victims to Challengers. International Affairs, Vol. 72, No. 3, pp. 507-520. https://doi.org/10.2307/2625554.

Cohen, Robin 1997. Global Diasporas: An Introduction. Seattle: University of Washington Press.

Friedman, Jonathan 1994. Cultural Identity and Global Process. London: Sage.

Giordano, Christian 2003. Studying Networks Nowadays: On the Utility of a Notion. In: D. Torsello \& M. Pappova (eds.) Social Networks in Movement: Time, Interaction, and Interethnic Spaces in Central Eastern Europe. Šamorin \& Dunajska Streda: Forum Minority Research Institute, pp. 9-14. Available at http://mek. oszk.hu/01800/01847/01847.pdf, last accessed on 18 February 2020.

Giordano, Christian 2011. Investigating Migrations: From Diaspora Studies to Transnationalism. In: V. Čiubrinskas (ed.) Lietuviškasis identitetas šiuolaikinès emigracijos kontekstuose. [Lithuanian Identity in Contemporary Migration Settings.] Kaunas: Vytauto Didžiojo universitetas, pp. 59-70. Available at https://www.vdu. lt/cris/bitstream/20.500.12259/192/1/ISBN9789955127505.pdf, last accessed on 18 February 2020.

Giordano, Christian 2013. Corporate Groups, Factions and Networks: Social Organization of the Chinese Diaspora in the Straits of Malacca: The Case of Penang. In: W. Kokot \& C. Giordano \& M. Gandelsman-Trier (eds.) Diaspora as a Resource: Comparative Studies in Strategies, Networks and Urban Space. Münster: LIT, pp. 199-221.

Glick Schiller, Nina \& Fouron, Georges Eugene 2001. Georges Woke Up Laughing: LongDistance Nationalism and the Search for Home. Durham, NC: Duke University Press.

Glick Schiller, Nina \& Caglar, Ayse 2008. Migrant Incorporation and City Scale: Towards a Theory of Locality in Migration Theories. Willy Brandt Series of Working Papers in International Migration and Ethnic Relations 2/07. Malmö: Malmö University. Available athttp://muep.mau.se/handle/2043/5935, last accessed on 18February 2020.

Kelly, Mary E. 2000. Ethnic Pilgrimages: People of Lithuanian Descent in Lithuania. Sociological Spectrum, Vol. 20, No. 1, pp. 65-91. http://dx.doi. org/10.1080/027321700280035. 
Kockel, Ullrich 2002. Regional Culture and Economic Development: Explorations in European Ethnology. Aldershot: Ashgate.

Kopnina, Helen 2005. East to West Migration: Russian Migrants in Western Europe. Aldershot: Ashgate.

Kripienè, Ieva 2012. Construction of Identities in Transnational Migration: Contemporary Immigrants from Lithuania in the United States of America. Diss. (PhD Thesis). Vytautas Magnus University. Available at https://elaba.lvb.lt/primo-explore/full display?vid=ELABA\&docid=ELABAETD1778209\&context=L\&lang=en_US, last accessed on 18 February 2020.

Krohn-Hansen, Christian 2003. Into Our Time: The Anthropology of Political Life in the Era of Globalization. In: T.H. Eriksen (ed.) Globalization: Studies in Anthropology. London: Pluto Press, pp. 78-98. DOI: 10.2307/j.ctt18fs8zb.8.

Kučas, Antanas 1975. Lithuanians in America. Boston: Encyclopedia Lituanica Press. Kuzmickaite, Daiva K. 2003. Between Two Worlds: Recent Lithuanian Immigrants in Chicago (1988-2000). Vilnius: Versus Aureus.

Kuznecovienè, Jolanta 2009. Lietuvių imigrantų tautinès tapatybės darybos strategijos Airijoje, Anglijoje, Ispanijoje ir Norvegijoje. [Strategies of National Identity Construction of the Lithuanian Immigrants in Ireland, Spain, Norway and the UK.] Filosofija. Sociologija / Philosophy. Sociology, Vol. 20, No. 4, pp. 283-291. Available at http://mokslozurnalai.lmaleidykla.lt/publ/0235-7186/2009/4/283-291. pdf, last accessed on 18 February 2020.

LAC 2018 = LAC Charter. Lithuanian American Community, Inc. Available at http:// lithuanian-american.org/m/about-lac/rules-regulations/\#charter, last accessed on 4 February 2020.

Lankauskas, Gediminas 2014. Missing Socialism Again? The Malaise of Nostalgia in Post-Soviet Lithuania. In: Olivia Angé \& David Berliner (eds.) Anthropology and Nostalgia. New York \& Oxford: Berghahn, pp. 35-60. Available at https://www. berghahnbooks.com/downloads/chapters/AngeAnthropology_02.pdf, last accessed on 30 January 2020.

Ledeneva, Alena V. 1998. Russia's Economy of Favours: Blat, Networking and Informal Exchange. Cambridge: Cambridge University Press.

Ledeneva, Alena V. (ed.) 2018. The Global Encyclopaedia of Informality. Vol.1. Towards Understanding of Social and Cultural Complexity. London: UCL Press. http:// dx.doi.org/10.14324/111.9781911307907.

Levitt, Peggy 1998. Social Remittances: Migration Driven Local-Level Forms of Cultural Diffusion. International Migration Review, Vol. 32, No. 4, pp. 926-948. http:// dx.doi.org/10.1177/019791839803200404.

Levitt, Peggy \& Glick Schiller, Nina 2004. Conceptualizing Simultaneity: A Transnational Social Field Perspective on Society. International Migration Review, Vol. 38, No. 3, pp. 1002-1039. http://dx.doi.org/10.1111/j.1747-7379.2004.tb00227.x.

Levitt, Peggy \& Lamba-Nieves, Deepak 2011. Social Remittances Revisited. Journal of Ethnic and Migration Studies, Vol. 37, No. 1, pp. 1-22. http://dx.doi.org/10.108 0/1369183X.2011.521361.

Liubinienè, Neringa 2009. Migrantai iš Lietuvos Šiaurès Airijoje: "savos erdvès" konstravimas. [Migrants from Lithuania in Northern Ireland: Construction of 'Own Space'.] Diss. (PhD Thesis). Vytautas Magnus University. 
Malkki, Liisa 1992. National Geographic: The Rooting of Peoples and the Territorialization of National Identity among Scholars and Refugees. Cultural Anthropology, Vol. 7, No. 1, pp. 24-44. http://dx.doi.org/10.1525/can.1992.7.1.02a00030.

Nic Craith, Máiréad 2004. Culture and Citizenship in Europe: Questions for Anthropologists. Social Anthropology, Vol. 12, No. 3, pp. 289-300. https://doi. org/10.1111/j.1469-8676.2004.tb00109.x.

Olwig, Karen Fog 2003. Global Places and Place-Identities: Lessons from Caribbean Research. In: T.H. Eriksen (ed.) Globalization: Studies in Anthropology. London: Pluto Press, pp. 58-77. DOI: 10.2307/j.ctt18fs8zb.7.

Olwig, Karen Fog \& Sorensen, Ninna N. 2002. Work and Migration: Life and Livelihoods in a Globalizing World. London \& New York: Routledge.

Parutis, Violetta 2006. Construction of Home by Polish and Lithuanian Migrants in the UK. Economics Working Paper No. 64. UCL School of Slavonic and East European Studies. Available at https://discovery.ucl.ac.uk/id/eprint/17498/, last accessed on 18 February 2020.

Parutis, Violetta 2013. At Home in Migration: The Social Practices of Constructing 'Home' among Polish and Lithuanian Migrants in London. Lambert Academic Publishing.

Parutis, Violetta 2014. 'Economic Migrants' or 'Middling Transnationals'? East European Migrants' Experiences of Work in the UK. International Migration, Vol. 52, No. 1, pp. 36-55. http://dx.doi.org/10.1111/j.1468-2435.2010.00677.x.

Rosaldo, Renato \& Flores, William V. 1997. Identity, Conflict, and Evolving Latino Communities: Cultural Citizenship in San Jose, California. In: W.V. Flores \& R. Benmayor (eds.) Latino Cultural Citizenship: Claiming Identity, Space, and Rights. Boston: Beacon Press, pp. 57-96.

Ryan, Louise \& Sales, Rosemary \& Tilki, Mary \& Siara, Bernadetta 2008. Social Networks, Social Support and Social Capital: The Experiences of Recent Polish Migrants in London. Sociology, Vol. 42, No. 4, pp. 672-690. http://dx.doi. org/10.1177/0038038508091622.

Safran, William 1991. Diasporas in Modern Societies: Myths of Homeland and Return. Diaspora: A Journal of Transnational Studies, Vol. 1, No. 1, pp. 83-99. https:// doi.org/10.1353/dsp.1991.0004.

Safran, William 2004. Deconstructing and Comparing Diasporas. In: Waltraud Kokot \& Khachig Tölölyan \& Carolin Alfonso (eds.) Diaspora, Identity and Religion: New Directions in Theory and Research. London \& New York: Routledge, pp. 9-24.

Senn, Alfred E. 2005. Lithuanians. Encyclopaedia of Chicago. Available at http:// encyclopedia.chicagohistory.org/pages/757.html, last accessed on 19 February 2020.

Vertovec, Steven 2009. Transnationalism: Key Ideas. London \& New York: Routledge.

Vertovec, Steven \& Cohen, Robin 1999. Migration, Diasporas and Transnationalism. Cheltenham, UK: Edward Elgar Publishing.

Vytis Čiubrinskas, Professor of Social and Cultural Anthropology at the Department of Sociology, Vytautas Magnus University, Kaunas, Lithuania, and Adjunct Associate Professor at the Department of Anthropology, Southern Illinois University, USA. His main research areas are anthropology of transnational migration and also ethnicity, nationalism, and memory studies.

vciubrin@siu.edu 